\title{
URGENSI PENETAPAN KRITERIA FAKIR MISKIN BAGI PENYALURAN ZAKAT DI INDONESIA
}

\author{
Kuntarno Noor Aflah \\ Sekolah Tinggi Agama Islam Negeri (STAIN) Kudus \\ e-mail: inimasaflah@gmail.com
}

\begin{abstract}
Poverty has many definitions, parameters, and standards. From the viewpoint of Islam, many theologians define and measure poverty by various terms and sizes. The difference among theologians' opinion is caused by poverty terms contained in the Qur'an and Hadits. "Fakir" and "poor" have many meanings. It allows a wide interpretation of the verse and word from theologians. It is also seen from the regulation point in Indonesia, there are many definitions, standards and parameters of poverty. The difference of point of view on determination of poverty criteria and regulations according to Islam in Indonesia shows that the ways of ijtihad by theologians and the government elements is very open. The absence of standard stipulation held, encouraging the writer to conduct a comparative research in this paper; through literacy research. Syafi'i sect does not specify a quantitative standard for poverty. Poverty is only categorized on requirement. As long as people are not able to cover $50 \%$ of their basic needs, they are called as fakir. If people are only able to cover close to $70 \%$ of their basic needs then they are categorized as poor. Meanwhile, according to Hanafi sect, the qualitative standards turned to the Syafi'i sect. Poor conditions are more severe than the fakir. Besides,
\end{abstract}




\section{Kuntarno Noor Aflah}

the quantitative standard of poverty is one nisab of zakat or the equivalent of 85 grams of gold. On the other hand, $B P S$ and BKKBN formulate the concept and standard of poverty by economic concepts. Poverty is conceptualized as the inability of someone to meet basic consumption needs of the formulation adapted to local conditions respectively.

Keywords: Poverty Criteria, Zakat Distribution, and Regulation.

\section{Pendahuluan}

Dilihat dari segi angka, jumlah penduduk miskin di negeri kita tecinta ini mengalami peningkatan. Menurut data yang dirilis Badan Pusat Statistik (BPS), Senin 17 Juli 2017 menunjukkan, bahwa total jumlah penduduk miskin di Indonesia masih berada di kisaran 27,77 juta orang pada Maret 2017. Angka ini naik sekitar 6.900 orang dibandingkan September 2016 (Kompas, 7 Juli 2017: 4).

Meningkatnya jumlah orang miskin sejak tahun 2014 hingga tahun 2017 menurut BPS disebabkan karena penghapusan subsidi harga bahan bakar minyak pada akhir 2014. Pencabutan subsidi tersebut tanpa diikuti stabilisasi harga, terutama harga beras dan bahan pangan lainnya serta transportasi umum, yang menghasilkan inflasi 4,03 persen pada periode September 2014 Maret 2015 (Kompas, 17 September 2015).

Kondisi di atas dirasakan sejak Maret 2015. Pada saat itu, harga-harga kebutuhan pokok semakin meningkat. Hal ini bukan disebabkan karena kenaikan harga Bahan Bakar Minyak (BBM) saja, melainkan melemahnya nilai tukar rupiah terhadap dolar AS, masalah distribusi, dan masalah-masalah teknis lain, seperti mafia yang menguasai kebutuhan pokok sehingga membuat harga kebutuhan pokok tambah meroket. Pertumbuhan ekonomi yang melambat pada tri wulan kedua dan ketiga tahun 2015, meningkatnya pengangguran karena adanya pemutusan hubungan kerja (PHK) di sejumlah perusahaan, akan memberi andil naiknya deret angka kemiskinan. Dalam kondisi tersebut 
ancaman angka kemiskinan pun menjadi sangat besar (Republika, 16 September 2015: 6).

Hingga Maret 2017 jenis komoditi makanan yang berpengaruh besar terhadap nilai Garis Kemiskinan di perkotaan maupun di pedesaan adalah beras, rokok kretek filter, telur ayam ras, daging ayam ras, mie instan, gula pasir, kopi bubuk dan kopi instan (sachet), dan bawang merah. Sementara itu, untuk komoditi bukan makanan yang besar pengaruhnya adalah biaya perumahan, listrik, bensin, pendidikan, angkutan, kesehatan, dan perlengkapan mandi (Berita Resmi BPS, 2017).

Kata kemiskinan yang digunakan dalam paper ini merupakan perpaduan antara pengertian fakir dan miskin yang kemudian disatukan penyebutannya menjadi kemiskinan, sebagai sebuah sifat yang melekat dalam diri fakir dan miskin. Biasanya konteks kemiskinan dari sudut pandang regulasi dan fikih adalah untuk menyebut kondisi-kondisi tertentu secara ekonomi maupun finansial.

Kita tahu bahwa kemiskinan memiliki banyak definisi, dan sebagian besar sering mengaitkan konsep kemiskinan dengan aspek ekonomi. Berbagai upaya untuk mendifinisikan kemiskinan dan mengidentifikasi kemiskinan tersebut, sebenarnya dapat menghasilkan suatu konsep pemikiran yang dapat disederhanakan, namun faktanya masih berlum terdapat kesepakatan dalam merumuskan kriterianya.

Dalam UU No. 13 tahun 2011, tentang Penanganan Fakir Miskin, tidak disebutkan secara spesifik tentang kriteria fakir miskin. Dalam Ketentuan Umum Pasal 1, disebutkan fakir miskin adalah orang yang sama sekali tidak mempunyai mata pencaharian dan atau mempunyai sumber mata pencaharian tetapi tidak mempunyai kemampuan memenuhi kebutuhan dasar yang layak bagi kehidupan dirinya dan atau keluarganya (www. kemendagri.go.id). 


\section{Kuntarno Noor Aflah}

Sedangkan kewenangan penetapan kriteria fakir miskin diserahkan kepada Menteri yang menyelenggarakan urusan pemerintah di bidang sosial. Artinya di dalam UU ini, kewenangan menentukan kriteria fakir miskin atau kemiskinan diserahkan kepada lembaga terkait, dalam hal ini adalah Badan Pusat Statistik (BPS), dan BKKBN.

Kedua instansi pemerintah tersebut berbeda dalam menentukan parameter kemiskinan di Indonesia. Bahkan Bappenas dan Kementerian Sosial juga terkadang menentukan kriteria kemiskinan tersendiri. Meskipun banyak lembaga yang mengeluarkan kriteria kemiskinan, namun secara formal dan resmi pemerintah Indonesia menggunakan data yang dibuat oleh Badan Pusat Statistik (BPS).

Perbedaan sudut pandang dalam penentuan kriteria kemiskinan dari pemerintah Indonesia, menujukkan tidak adanya ketentuan yang baku yang dijadikan sebagai pegangan oleh semua pihak. Meskipun demikian, setidaknya kecenderungan untuk saling melengkapi antara kriteria satu dengan yang lainnya, sudah sangat terlihat.

Islam adalah agama yang sangat lengkap dalam melihat permasalahan. Dengan demikian, tentu tidak tinggal diam membahas kriteria kemiskinan. Terdapat banyak ayat dalam Al Quran dan Hadits yang bisa dijadikan rujukan dalam memahami kriteria kemiskinan. Tentunya melalui pemahaman para ulama dalam berbagai macam kitab-kitab fikihnya. Mengapa melalui pemahaman para ulama, karena dalam konteks Al-Quran dan Sunnah terdapat banyak istilah yang artinya merujuk pada arti kemiskinan secara umum.

Ada dua istilah yang sangat dikenal berkaitan dengan kemiskinan, yaitu fakir dan miskin. Kedua istilah ini yang kemudian menjadi fokus pembahasan penulis dalam menentukan kriteria kemiskinan. Sedangkan dari bahasa aslinya, yakni bahasa Arab kata miskin diambil dari kata "sakana" yang berarti diam atau tenang, sedangkan kata faqîr diambil dari kata faqara pada 
mulanya berarti tulang punggung. Faqîr adalah orang yang patah tulang punggunggnya, dalam arti bahwa beban yang dipikulnya terlalu berat sehingga mematahkan tulang punggungnya. (M. Quraish Shihab, 1996: 344)

Dengan berdasar pada pengertian-pengertian di atas dapat ditarik benang merah bahwa kemiskinan adalah ketidakmampuan memenuhi kebutuhan hidup, baik karena tidak memiliki harta dan mata pencaharian sekaligus, maupun karena harta dan mata pencaharian yang tidak mencukupi.

Kriteria dan parameter inilah yang akan dibahas secara lebih mendalam dalam uraian ini, dengan membandingkan bagaimana kriteria dan parameter kemiskinan menurut regulasi di Indonesia.

\section{Pembahasan}

\section{Kriteria fakir miskin menurut regulasi}

Pemerintah Indonesia telah mengeluarkan UndangUndang tentang Penanganan Kemiskinan, yakni UU No. 13 tahun 2011, tentang Penanganan Fakir Miskin. Regulasi ini dimaksudkan untuk menangani permasalahan kemiskinan di Indonesia. Namun setelah ditelaah dan dibaca secara lebih mendalam, ternyata di dalam UU ini tidak didapati secara khusus tentang kriteria fakir miskin. Dalam Ketentuan Umum Pasal 1, disebutkan fakir miskin adalah orang yang sama sekali tidak mempunyai mata pencaharian dan atau mempunyai sumber mata pencaharian tetapi tidak mempunyai kemampuan memenuhi kebutuhan dasar yang layak bagi kehidupan dirinya dan atau keluarganya.

Pada Pasal 8, disebutkan penetapan kriteria fakir miskin. Namun lagi-lagi di pasal ini tidak menyebutkan kriteria secara spesifik. Pasal ini hanya berbicara tentang wewenang dalam penetapan kriteria kemiskinan, bahwa kewenangan penetapan kriteria fakir miskin diserahkan kepada Menteri yang menyelenggarakan urusan pemerintah di bidang sosial. Ayat (1) 


\section{Kuntarno Noor Aflah}

menyebutkan : Menteri menetapkan kriteria fakir miskin sebagai dasar untuk melaksanakan penanganan fakir miskin. Ayat (2) Dalam menetapkan kriteria sebagaimana yang dimaksud ayat (1) Menteri berkordinasi dengan kementerian dan lembaga terkait. Ayat (3) Kriteria sebagaimana yang dimaksud ayat (1) menjadi dasar bagi lembaga yang menyelenggarakan urusan pemerintahan di bidang kegiatan statistik untuk melakukan pendataan. Artinya di dalam UU ini, kewenangan menentukan kriteria fakir miskin atau kemiskinan diserahkan kepada lembaga terkait, dalam hal ini adalah Badan Pusat Statistik (BPS).

Bukan hanya BPS dan BKKBN, instansi terkait lainnya yang juga membuat kriteria kemiskinan adalah BKKBN (Badan Koordinasi Keluarga Berencana Nasional). Secara rutin BPS dan BKKBN mengeluarkan data kemiskinan yang dijadikan rujukan pemerintah dalam penanggulangan kemiskinan. Rumusan konsep, standard, parameter dan kriteria yang dibuat oleh BPS dan BKKN itulah yang kemudian dijadikan sebagai pedoman penulis dalam merumuskan kriteria kemiskinan menurut regulasi di Indonesia, sebagaimana di bahas dalam paper ini.

Dengan tidak adanya regulasi yang secara khusus membahas tentang kemiskinan, kemudian para pakar yang concern di bidang kemiskinan merumuskan definisi, pengertian, konsep dan kriteria kemiskinan secara beragam. Melalui analisis pemikirannya, masing-masing pakar membuat rumusan kemiskinan sendiri-sendiri. Mereka mengacu pada pendapat pakar nasional maupun internasional dalam menentukan kriteria dan standar kemiskinan. Apalagi kemiskinan sudah menjadi concern seluruh negara-negara di dunia, maka menurut hemat penulis, pendapat pakar nasional maupun internasional dapat menjadi acuan dalam merumuskan kemiskinan, meskipun secara spesifik tekstual tidak dituangkan dalam regulasi di pemerintahan ini. 


\section{Kemiskinan menurut BPS (Badan Pusat Statistik)}

Badan Pusat Statistik (BPS) sebagai instansi pemerintah yang memilliki otoritas menentukan kriteria dan standar kemiskinan membagi kemiskinan menjadi dua macam, yaitu kemiskinan relatif dan kemiskinan absolut.

Pertama, Kemiskinan Relatif. Kemiskinan relatif merupakan kondisi miskin karena pengaruh kebijakan pembangunan yang belum mampu menjangkau seluruh lapisan masyarakat sehingga menyebabkan ketimpangan pada distribusi pendapatan. Standar minimum disusun berdasarkan kondisi hidup suatu negara pada waktu tertentu dan perhatian terfokus pada golongan penduduk "termiskin", misalnya 20 persen atau 40 persen lapisan terendah dari total penduduk yang telah diurutkan menurut pendapatan/ pengeluaran. Kelompok ini merupakan penduduk relatif miskin. Dengan demikian, ukuran kemiskinan relatif sangat tergantung pada distribusi pendapatan/ pengeluaran penduduk. (BPS, 2014: 6)

Dalam prakteknya, negara kaya mempunyai garis kemiskinan yang relative lebih tinggi daripada negara miskin seperti pernah dilaporkan oleh Ravallion sebagaimana dikutip oleh BPS. Paper tersebut menjelaskan mengapa, misalnya, angka kemiskinan resmi (official figure) pada awal tahun 1990an mendekati 15 persen di Amerika Serikat dan juga mendekati 15 persen di Indonesia (negara yang jauh lebih miskin). Artinya, banyak dari mereka yang dikategorikan miskin di Amerika Serikat akan dikatakan sejahtera menurut standar Indonesia.

Pada saat negara menjadi lebih kaya (sejahtera), negara tersebut cenderung merevisi garis kemiskinannya menjadi lebih tinggi, dengan mengecualikan Amerika Serikat, di mana garis kemiskinan pada dasarnya tidak berubah selama hampir empat dekade. Misalnya, Uni Eropa umumnya mendefinisikan penduduk miskin adalah mereka yang mempunyai pendapatan per kapita di bawah 50 persen dari median/rata-rata pendapatan. 


\section{Kuntarno Noor Aflah}

Ketika median/rata-rata pendapatan meningkat, garis kemiskinan relatif juga meningkat. (BPS, 2014: 7)

Dalam hal mengidentifikasi dan menentukan sasaran penduduk miskin, maka garis kemiskinan relatif cukup untuk digunakan, dan perlu disesuaikan terhadap tingkat pembangunan negara secara keseluruhan. Garis kemiskinan relatif tidak dapat dipakai untuk membandingkan tingkat kemiskinan antar Negara dan waktu, karena tidak mencerminkan tingkat kesejahteraan yang sama.

Kedua, Kemiskinan Absolut. Kemiskinan absolut atau mutlak berkaitan dengan standar hidup minimum suatu masyarakat yang diwujudkan dalam bentuk garis kemiskinan. Pembentukan garis kemiskinan tergantung pada definisi mengenai standar hidup minimum. Sehingga kemiskinan absolut ini bisa diartikan dengan melihat seberapa jauh perbedaan antara tingkat pendapatan seseorang dengan tingkat pendapatan yang dibutuhkan untuk memenuhi kebutuhan dasarnya.

Kemiskinan secara absolut ditentukan berdasarkan ketidakmampuan untuk mencukupi kebutuhan pokok minimum seperti pangan, sandang, kesehatan, perumahan dan pendidikan yang diperlukan untuk bisa hidup dan bekerja. Kebutuhan pokok minimum diterjemahkan sebagai ukuran finansial dalam bentuk uang. Nilai kebutuhan minimum kebutuhan dasar tersebut dikenal dengan istilah garis kemiskinan. Penduduk yang pendapatannya di bawah garis kemiskinan digolongkan sebagai penduduk miskin. (BPS, 2014: 7)

Ukuran kemiskinan yang sering digunakan Bank Dunia adalah menggunakan batas kemiskinan PPP US\$ perkapita per hari. Batas kemiskinan menggunakan PPP US\$ ini sering disalahartikan dengan menggunakan nilai tukar biasa (exchange rate) untuk mendapatkan garis kemiskinan. Sehingga ada anggapan, jika misalkan nilai tukar adalah Rp. 14.000 per satu dolar, maka garis kemiskinan 1 PPP US\$ per kapita per hari menjadi Rp 420.000 per kapita per bulan, padahal bukan seperti 
ini pengertian yang dimaksud. Nilai tukar yang digunakan di dalam penghitungan garis kemiskinan 1 PPP US\$ adalah nilai tukar dolar PPP (Purchasing Power Parity). Nilai tukar PPP menunjukkan daya beli mata uang di suatu negara, dalam hal ini US\$, untuk membeli barang dan jasa yang "sama" di Negara lain. (BPS, 2014: 8)

Contoh sederhananya adalah sebagai berikut, apabila di Indonesia seseorang membeli beras seharga Rp 10.000 per liter, sementara di Amerika satu liter beras dengan kualitas yang sama harganya adalah 1 (satu) US\$, dengan nilai tukar biasa artinya Rp14.000, tetapi dengan pengertian nilai tukar PPP, maka orang di Indonesia yang membeli beras tadi dianggap telah membelanjakan 1 US\$, walaupun pada kenyataannya dia hanya mengeluarkan Rp 10.000 .

Saat ini, menurut BPS, ukuran yang digunakan oleh Bank Dunia adalah: a) PPP US \$ 1,25 perkapita per hari yang diperkirakan ada sekitar 1,38 miliar penduduk dunia yang hidup di bawah ukuran tersebut; b) PPP US \$ 2 perkapita per hari, yaitu sekitar 2,09 miliar penduduk yang hidup di bawah ukuran tersebut.

Dengan demikian, perbedaan konsep kemiskinan relatif dan kemiskinan absolut menurut BPS terletak pada standar penilaiannya. Standar penilaian kemiskinan relative adalah standar kehidupan yang ditentukan dan ditetapkan secara subyektif oleh masyarakat setempat dan bersifat lokal serta mereka yang berada di bawah standar penilaian tersebut dikategorikan sebagai miskin secara relatif. Sedangkan standar penilaian kemiskinan secara absolut merupakan standar kehidupan minimum yang dibutuhkan untuk memenuhi kebutuhaan dasar yang diperlukan, baik makanan maupun non makanan. Standar kehidupan minimum untuk memenuhi kebutuhan dasar ini disebut sebagai garis kemiskinan.

Pada tahun 2000 BPS pernah melakukan Studi Penentuan Kriteria Penduduk Miskin (SPKPM 2000) untuk mengetahui 


\section{Kuntarno Noor Aflah}

karakteristik-karakteristik rumah tangga yang mampu mencirikan kemiskinan secara konseptual (pendekatan kebutuhan dasar/ garis kemiskinan). (BPS, 2014: 8)

Dari hasil SPKPM 2000 tersebut, diperoleh 8 variabel yang dianggap layak dan operasional untuk penentuan rumah tangga miskin di lapangan. Skor 1 mengacu kepada sifat-sifat yang mencirikan kemiskinan dan skor 0 mengacu kepada sifatsifat yang mencirikan ketidakmiskinan. Kedelapan variabel tersebut adalah:

1. Luas Lantai Perkapita :

$$
\begin{aligned}
& \cdot \quad<=8 \mathrm{M}^{2}=(\text { skor } 1) \\
& \cdot \quad>8 \mathrm{M}^{2}=(\text { Skor } 0)
\end{aligned}
$$

2. Jenis Lantai :

- Tanah (Skor 1)

- Bukan Tanah (Skor 0)

3. Air Minum Ketersediaan Air Bersih :

- Air Hujan / Sumur Tidak Terlindung (Skor 1)

- Ledeng/PAM/Sumur Terlindung (Skor 0)

4. Jenis Jamban/WC :

- Tidak Ada (Skor 1)

- Bersama / Sendiri (Skor 0)

5. Kepemilikan Aset :

- Tidak Punya Aset (Skor 1)

- Punya Aset (Skor 0)

6. Pendapatan (total pendapatan perbulan)

- $<=\operatorname{Rp} 350.000,-($ Skor 1$)$

- $\quad>\operatorname{Rp} 350.000,-($ Skor 0$)$

7. Pengeluaran (total pengeluaran untuk makanan)

- 80 persen $+($ Skor 1$)$

- $\quad<8$ persen (Skor 0)

8. Konsumsi lauk pauk (daging, telur, ikan, ayam)

- Tidak ada/ada tapi tidak bervariasi (Skor 1) Ada, bervariasi (Skor 0)

Kedelapan variabel yang digunakan BPS di atas, diperoleh dengan menggunakan metode stepwise logistic regression dan 
misklasifikasi yang dihasilkan sekitar 17 persen. Hasil analisis deskriptif dan uji Chi-Square juga menunjukkan bahwa kedelapan variabel terpilih tersebut sangat terkait dengan fenomena kemiskinan dengan tingkat kepercayaan sekitar 99 persen. Skor batas yang digunakan adalah 5 (lima) yang didasarkan atas modus total skor dari domain rumah tangga miskin secara konseptual. Dengan demikian apabila suatu rumah tangga mempunyai minimal 5 (lima) ciri miskin maka rumah tangga tersebut digolongkan sebagai rumah tangga miskin. (BPS, 2014: 15).

\section{Kemiskinan menurut BKKBN}

BKKBN memang tidak secara resmi mengeluarkan kriteria kemiskinan. Namun BKKBN dalam sebuah papernya di sebuah seminar pada awal tahun 2014 yang digagas oleh BAZNAS (Badan Amil Zakat Nasional), yang secara langsung penulis mengikuti seminar tersebut, menjelaskan tentang kriteria kemiskinan versi BKKBN.

Untuk menghitung tingkat kesejahteraan, BKKBN pata tahun 1999 melakukan program yang disebut sebagai Pendekatan Keluarga. Pendataan Keluarga dilakukan dengan tujuan untuk memperoleh data dasar kependudukan dan keluarga dalam rangka program pembangunan dan pengentasan kemiskinan. Terdapat empat kelompok data yang dihasilkan oleh Pendataan Keluarga, yaitu:

1) Data Demografi, misalnya jumlah jiwa dalam keluarga menurut jenis kelamin, dan lain-lain;

2) Data Keluarga Berencana, misalnya Pasangan Usia Subur (PUS), peserta KB, Data Tahapan Keluarga Sejahtera, yaitu jumlah keluarga yang masuk dalam katagori keluarga pra-sejahtera, sejahtera I, II dan III.

Data kemiskinan didapat dengan melalui pentahapan keluarga sejahtera yang dibagi menjadi lima tahap, yaitu Keluarga Pra Sejahtera (sangat miskin), Keluarga Sejahtera I (miskin), 


\section{Kuntarno Noor Aflah}

Keluarga Sejahtera II, Keluarga Sejahtera III dan Keluarga Sejahtera III plus.

Ada lima indikator yang harus dipenuhi agar suatu keluarga dikategorikan sebagai Keluarga Sejahtera I, yaitu:

1. Anggota keluarga melaksanakan ibadah sesuai agama yang dianut masing-masing.

2. Seluruh anggota keluarga pada umumnya makan 2 kali sehari atau lebih.

3. Seluruh anggota keluarga mempunyai pakaian yang berbeda di rumah, sekolah, bekerja dan bepergian.

4. Bagian terluas lantai rumah bukan dari tanah.

5. Bila anak sakit atau PUS (Pasangan Usia Subur) ingin mengikuti KB. (Sudibyo Alimoeso, 2014 : 3 - 5).

Selanjutnya mereka yang dikategorikan sebagai Keluarga Pra-Sejahtera adalah keluarga-keluarga yang tidak memenuhi salah satu dari 5 (lima) indikator di atas. Pendekatan BKKBN ini dianggap sebagian kalangan masih kurang realistis karena konsep keluarga Pra Sejahtera dan KS I sifatnya normatif dan lebih sesuai dengan keluarga kecil/inti, di samping ke 5 indikator tersebut masih bersifat sentralistik dan seragam yang belum tentu relevan dengan keadaan dan budaya lokal.

Berikut ini perbandingan aspek kemiskinan menurut BPS dan BKKBN, yang disusun oleh Thabrany, Hasbullah, dkk dan dikutip oleh Titik Kurnianingsih (Titik Kurnianingsih, 2014: 46).

\section{Tabel 1.}

\section{Perbandingan Aspek Kemiskinan Menurut BPS dan BKKBN}

\begin{tabular}{lll}
\hline \multicolumn{1}{c}{ Aspek } & Badan Pusat Statistik & \multicolumn{1}{c}{ Data BKKBN } \\
\hline Metode & Survey Susenas & Sensus \\
\hline $\begin{array}{l}\text { Cakupan } \\
\text { Wilayah }\end{array}$ & $\begin{array}{l}\text { Hanya bisa di break } \\
\text { down sampai kabupaten } \\
\text { / kota }\end{array}$ & Tersedia sampai desa \\
\hline Manajemen Data & $\begin{array}{l}\text { Terorganisir secara baik } \\
\text { di tingkat pusat }\end{array}$ & Kurang terorganisir \\
\hline
\end{tabular}


Urgensi Penetapan Kriteria Fakir Miskin bagi Penyaluran Zakat....

\begin{tabular}{|c|c|c|}
\hline Waktu & $\begin{array}{l}\text { Dilakukan secara } \\
\text { periodic } 3 \text { tahun sekali }\end{array}$ & $\begin{array}{l}\text { Dilakukan secara } \\
\text { periodic setiap } 1 \\
\text { tahun sekali }\end{array}$ \\
\hline Unit Observasi & Rumah tangga & Keluarga \\
\hline Pendekatan & Basic need (ekonomi) & $\begin{array}{l}\text { Mencakup non } \\
\text { ekonomi }\end{array}$ \\
\hline Penghitungan & $\begin{array}{l}\text { Secara kuantitatif. } \\
\text { Dilakukan secara } \\
\text { obyektif dengan } \\
\text { menggunakan nilai } \\
\text { moneter atas sejumlah } \\
\text { komoditas yang } \\
\text { ditentukan }\end{array}$ & $\begin{array}{l}\text { Secara kualitataif. } \\
\text { Penghitungannya } \\
\text { bersifat kategorik } \\
\text { atas sejumlah } \\
\text { indokator yang } \\
\text { berifat subyektif } \\
\text { dan tidak dilakukan } \\
\text { kuantifikasi secara } \\
\text { moneter atas } \\
\text { sejumlah indicator } \\
\text { yang ditentukan }\end{array}$ \\
\hline $\begin{array}{l}\text { Komoditas yang } \\
\text { diukur }\end{array}$ & $\begin{array}{l}\text { Komoditas makanan } \\
\text { dan non makanan } \\
\text { dalam suatu bundle }\end{array}$ & $\begin{array}{l}\text { Tidak disebutkan } \\
\text { secara spesifik }\end{array}$ \\
\hline Indikator & Lebih obyektif & Lebih subyektif \\
\hline Kegunaan & $\begin{array}{l}\text { Baik untuk perencanaan } \\
\& \text { analisis }\end{array}$ & $\begin{array}{l}\text { Baik untuk } \\
\text { pelaksanaan di } \\
\text { lapangan }\end{array}$ \\
\hline
\end{tabular}

Meskipun demikian penulis memandang bahwa upaya yang dilakukan BKKBN untuk merumuskan kriteria dan standar kemiskinan telah dilakukan dengan sangat baik. Terlepas apakah kemudian standard dan kriteria tersebut digunakan atau tidak, diperdebatkan ataupun tidak, itu tergantung dari sudut pandang mana pihak lain yang menilai tersebut.

\section{Kriteria fakir miskin menurut fiqh}

Ada dua istilah yang sangat dikenal berkaitan dengan kemiskinan, yaitu kata fakir dan miskin. Dari bahasa aslinya (Arab) kata faqîr dari asal kata faqara yang pada mulanya berarti tulang punggung. Faqîr adalah orang yang patah tulang punggunggnya, dalam arti bahwa beban yang dipikulnya terlalu berat sehingga mematahkan tulang punggungnya, sedangkan 


\section{Kuntarno Noor Aflah}

miskin terambil dari kata "sakana" yang berarti diam atau tenang. (M. Quraish Shihab, 1996: 449)

Di dalam buku Ensiklopedi Hukum Islam dijelaskan tentang pengertian fakir dan miskin. Fakir adalah orang yang berhajat. Miskin adalah orang yang tidak berharta, serba kekurangan. Kata faqîr dijumpai dalam Al-Quran sebanyak 12 kali dan kata miskîn disebut sebanyak 15 kali yang masing-masing digunakan untuk pengertian yang bermacam-macam (Ensiklopedi Hukum Islam, 2001: 302).

Raghib al-Isfahani (w. 502 H/1108M), ahli fikih dan ahli tafsir, sebagaimana dikutip M. Quraish Shihab, menyebutkan empat macam pengertian fakir. Pertama, fakir dalam arti orang yang memerlukan kebutuhan hidup yang primer, yaitu makanan, minuman, tempat tinggal, dan keamanan. Kedua, fakir dalam arti orang yang tidak dapat memenuhi kebutuhan hidupnya yang primer, tetapi ia dapat menjaga dirinya dari meminta-minta. Ketiga, fakir dalam arti fakir jiwanya. Ini termasuk golongan fakir yang paling buruk karena dapat mendorong orang ini kepada kekafiran. Keempat, dalam arti orang yang selalu merasa butuh kepada petunjuk dan bimbingan Allah, sehingga orang tersebut tidak merasa sombong (M. Quraish Shihab, 1996: 449).

Pengertian fakir selanjutnya dibahas dalam ilmu fikih. Sayid Sabiq, ahli fikih dari Mesir, mengatakan bahwa yang tergolong orang fakir adalah orang yang tidak memiliki harta sebanyak satu nishab (jumlah minimal harta kekayaan yang harus dikeluarkan zakatnya dalam waktu tertentu). Dari sini ulama fikih memahami bahwa orang yang memiliki harta sebanyak satu nishab zakat telah dinamakan kaya, sedangkan yang memiliki kurang dari satu nishab zakat, dinamakan fakir (Ensiklopedi Hukum Islam, 2001: 302).

Menurut Imam Abu Hanifah, fakir adalah orang yang mempunyai harta kurang dari satu nishab atau mempunyai harta satu nishab atau lebih tetapi habis digunakan untuk memenuhi kebutuhan hidupnya. Adapun Imam Mâlik mengatakan bahwa 
fakir adalah orang yang mempunyai harta yang jumlahnya tidak mencukupi untuk mencukupi kebutuhan hidupnya dalam masa satu tahun. Imam As-Syâfi'î mengatakan bahwa fakir adalah orang yang tidak mempunyai harta dan usaha atau mempunyai harta dan usaha tetapi kurang dari setengah kebutuhan hidupnya dan tidak ada orang yang berkewajiban menanggung biaya hidupnya. Imam Ahmad bin Hambal mengatakan bahwa fakir adalah orang yang tidak mempunyai harta atau mempunyai harta tetapi kurang dari setengah keperluannya (Ensiklopedi Hukum Islam, 2001: 302)

Sebagaimana kata "fakir", kata "miskin" pun mengalami pengertian yang bermacam-macam. Imam Abû Hanîfah dan Imam Mâlik mengatakan bahwa orang miskin adalah orang yang memiliki harta setengah dari kebutuhan hidupnya atau lebih tetapi tidak mencukupi. Dari segi kekurangan harta yang dimilikinya dan kedudukannya sebagai salah satu sebagai penerima zakat, tampak ada perbedaan.

Dalam kaitan ini terdapat pula dua istilah assâ'il dan al-mahrûm, sebagaimana terdapat dalam ayat 19 surat AdzDzâriyat.

Kata as-sâil pada ayat tersebut, menurut Syekh Muhammad Musthafâ Al-Marâghî (1881-1945), ahli tafsir dari Mesir adalah orang miskin yang meminta-minta, sedangkan al-mahrûm adalah orang miskin yang tidak memiliki harta tetapi ia tidak meminta-minta sehingga ia tidak diketahui di mana ia berada, dan karenanya ia tidak pula mendapatkan bagian dari zakat (Ensiklopedi Hukum Islam, 2001: 302)

Dari 12 kata fakir yang terdapat dalam Al-Quran, terdapat 6 (enam) kategori yang terkait dengan hukum. Pertama, fakir yang tergolong sebagai orang yang berhak memperoleh bagian dari daging kurban yang dilakukan oleh orang yang mengerjakan ibadah haji (Al-Quran 22: 28)

Kedua, fakir yang tergolong sebagai orang yang boleh memakan harta anak yatim yang diurusnya dengan cara yang 


\section{Kuntarno Noor Aflah}

baik dan tidak melampaui batas (Al-Quran, 4: 6). Ketiga, fakir yang termasuk orang yang boleh menerima sedekah secara terangterangan agar menjadi contoh bagi orang lain (Al-Quran, 2: 273). Keempat, fakir yang termasuk salah seorang yang berhak menerima zakat Al-(Quran, 9: 60). Kelima, fakir yang berhak mendapatkan bagian dari harta rampasan perang atau ghanimah (Al-Quran, 59: 6). Keenam, fakir yang berhak memperoleh pembelaan yang adil ketika ia melakukan pelanggaran yang tidak disengaja (Al-Quran, 4: 135)

Adapun orang miskin memperolah hak-hak sebagai berikut: Pertama, orang miskin yang termasuk salah seorang yang berhak memperoleh harta dari fidyah atau denda yang tidak dapat melaksanakan kewajiban agama karena udzur (Al-Quran, 2: 184). Kedua, orang miskin yang berhak mendapatkan perlindungan atas hak-haknya (Al-Quran, 17: 26). Ketiga, orang miskin yang berhak mendapatkan dana yang diperoleh dari kafârat yang dibayarkan oleh orang yang melakukan dzihâr (perkataan suami terhadap istrinya dengan ibunya sendiri (Al-Quran, 58 :3-4). Keempat, orang miskin yang mendapatkan dana yang diperoleh dari kafârat yang dibayar oleh orang yang melanggar sumpahnya secara sengaja (Al-Quran, 5: 89). Kelima, orang miskin yang mendapatkan dana dari orang yang melanggar larangan pada waktu melakukan ihram (Al-Quran, 5: 95). Keenam, orang miskin yang termasuk salah seorang yang boleh meminta harta dari rampasan perang (Al-Quran, 8: 41). Ketujuh, orang miskin yang boleh menerima harta dari zakat (Al-Quran, 9: 60).

Terdapat perbedaan interpretasi ulama fikih dalam mengdefinisikan orang fakir. Imam Abû Hanîfah sebagaimana disebutkan dalam buku Ensiklopedi Hukum Islam, berpendapat orang fakir adalah orang yang tidak memiliki penghasilan tetap untuk memenuhi kebutuhan hidup sehari-hari (Ensiklopedi Hukum Islam, 1996-1997).

Adapun menurut jumhur ulama, fakir adalah orang-orang yang tidak mempunyai harta atau penghasilaan layak untuk 
memenuhi kebutuhan sandang, pangan, tempat tinggal, dan segala keperluan pokok lainnya, baik untuk dirinya sendiri maupun untuk keluarga dan orang-orang yang menjadi tanggungannya.

Sedangkan dalam mendefinisikan orang miskin kedua golongan ulama di atas berbeda pendapat. Menurut Imam Abu Hanifah orang miskin adalah orang yang memiliki pekerjaan tetap tetapi tidak dapat mencukupi kebutuhannya sehari-hari. Jumhur ulama mengatakan bahwa orang miskin adalah yang yang mempunyai harta atau penghasilan layak untuk memenuhi kebutuhan diri dan tanggungannya tetapi penghasilan itu tidak mencukupinya. Akan tetapi Imam Abû Yusuf dan Ibn Qâsim, (tokoh fikih madzhab Maliki) tidak membedakan secara definitive kedua kelompok tersebut. Menurut mereka fakir dan miskin adalah dua istilah yang mengandung arti yang sama (Ensiklopedi Hukum Islam, 1996-1997).

Dalam literatur Islam, ada banyak kata untuk menyebut keberadaan kondisi umat yang tidak berdaya secara ekonomi. Kata-kata tersebut antara lain adalah as-sâil, al-mahrûm, al-faqîr, dan al-miskîn. Secara etimologis-sintaksis, kata tersebut bermakna 'meminta-minta', 'orang yang dihalangi kepemilikan harta', 'orang yang butuh' dan 'orang yang diam tidak punya apa-apa'.

Terkadang, pengertian dari salah satu kata tersebut dimaksud sebagai pengertian kata yang lain. Hanya saja, meskipun secara redaksional berbeda, tetapi kata-kata tersebut menunjuk satu kondisi, yaitu ketidakberdayaan ekonomi.

Ada juga kata miskin diambil dari kata al-sukûn yang berarti sedikit bergerak karena lemah fisik. Kata miskin (bentuk tunggal) dan kata masâkîn (bentuk jamak) serta maskanah (bentuk masdar) terdapat dalam dua puluh lima ayat, tersebar dalam sembilan belas surat.

Dalam praktiknya, fuqarâ $>$ sering digandengkan dengan kata masâkîn. Keduanya dipergunakan Al-Qur>an dalam arti orang-orang yang berhak memperoleh bagian zakat. Hal serupa 


\section{Kuntarno Noor Aflah}

juga diungkapkan oleh Mujâhid, lebih lanjut ia mengatakan alfaqîr adalah orang yang tidak meminta-minta, sementa al-masâkîn adalah orang yang meminta-minta. Ibnu Zaid dalam menafsirkan kata al-fuqarâ' adalah orang-orang yang tidak memintaminta kepada manusia sementara ia adalah orang-orang yang membutuhkan, sedangkan al-masâkîn diartikan sebaliknya yakni orang-orang yang meminta-minta kepada orang lain. Menurut Qatadah al-faqîr adalah orang yang mempunyai penyakit (man bihi al-zumanah), al-miskîn adalah orang yang sehat (orang yang tidak mempunyai penyakit) yang membutuhkan.

Dari ragam pendapat sebagaimana di atas, penulis dapat meringkas menjadi 5 kelompok pemahaman;

1. Kelompok yang mengatakan bahwa fakir adalah yang tidak meminta-minta, sedangkan miskin adalah yang meminta-minta.

2. Kelompok yang mengukur bahwa fakir miskin dengan sakit dan sehatnya badan. Fakir yang punya penyakit, sedangkan miskin adalah orang selamat atau sehat badannya.

3. Kelompok yang mengatakan bahwa fakir adalah orangorang yang berhijrah, sementara miskin adalah orang yang tidak berhijrah.

4. Kelompok yang mengatakan bahwa fakir miskin diukur dari lemahnya mereka dalam keuntungan.

5. Kelompok yang mengatakan bahwa fakir adalah orang Islam sementara miskin adalah orang ahli kitab.

Banyaknya pendapat ulama fikih tentang kriteria fakir miskin menunjukkan bahwa Al-Qur'an dan Sunnah belum melakukan standarisasi tentang kriteria kemiskinan. Hal ini dapat dimaklumi mengingat masa tersebut adalah masa pencarian bentuk, bukan masa pengembangan, apalagi pembakuan. Untuk itu, jika berbicara tentang standar, yang mungkin dilakukan adalah merujuk pada era madzhab. Mengingat keragaman madzhab, maka dalam analisis ini penulis menggunakan sampel 
Imam Nawawi sebagai representasi Syafi'iyyah dan Al-Kasani sebagai representasi Hanafiyyah. Madzhab lain tidak dianalisis secara khusus karena sejauh penelusuran penulis tidak ada perbedaan yang signifikan.

Al-Nawâwî dalam kitabnya Raudah al-Tâlibîn menuturkan tentang definisi fakir miskin adalah sebagai berikut: "Fakir adalah orang yang tidak mempunyai harta dan pekerjaan sama sekali untuk menutup kebutuhannya. Maka orang yang tidak dapat memenuhi kebutuhannya, seperti orang memerlukan 10 dirham, ia hanya memiliki 2 atau 3 dirham. Hal itu tidak menghilangkan sebutan fakir. Begitu juga rumah yang ditempati dan pakaian yang digunakan untuk memperindah dan mempercantik diri, sebagaimana disebutkan oleh pengarang kitab al-tahdzib dan yang lain. Mereka tidak mempertentangkan budak yang dibutuhkan sebagai pembantu. Itu merupakan perkara-perkara yang disamakan dengan tempat tinggal. Saya (al-Nawawi) berkata: "Ibnu Kaji telah menjelaskan dalam kitabnya al-Tajrid, budak sebagai pembantu itu seperti tempat tinggal dan itu sudah jelas" (Al-Nawawî, tt: 201-202)

Sementara dalam kitab Imâm An-Nawâwî dalam kitab Majmu'nya mengatakan: "Adapun hukum-hukumnya ada beberapa masalah, pertama : Hakikat fakir yang berhak atas bagian atas harta zakat. Imam Shaf'i dan ashabnya berkata : "Fakir adalah orang yang tidak mampu mencukupi kifayahnya baik dengan harta maupun dengan mata pencaharian. Ashabnya memberi penjelasan fakir adalah orang yang tidak mempunyai harta dan pekerjaan sama sekali menurut asalnya atau mempunyai sesuatu yang tidak mencukupi kifayahnya. Maka apabila ia tidak memiliki kecuali hanya sedikit bila dinisbatkan pada kebutuhannya, seperti yang butuh 10 dirham setiap harinya tetapi ian hanya memiliki 2 atau 3 dirham setiap harinya maka ia adalah fakir karena kemampuannya tidak mencukupi kifayahnya." (Al-Nawawî, tt: 190)

Melihat penjelasan di atas, fakir adalah orang yang mempunyai harta kurang dari separuh dilihat dari pemenuhan kebutuhannya, sampai orang yang tidak mempunyai apa-apa, baik harta maupun pekerjaan. Fakir tidak diukur dari nilai nominal uang atau harta yang dimiliki. Rumah, pakaian serta 


\section{Kuntarno Noor Aflah}

pembantu rumah tangga merupakan suatu kebutuhan yang tidak mempengaruhi sebutan fakir. Jadi orang dianggap fakir, tidak dilihat dari mewah atau tidaknya pakaian yang dipakai dan juga tidak dilihat dari fisik bangunan rumah. Lantai tanah atau keramik bahkan marmer sekalipun tidak bisa dijadikan ukuran fakir. Bisa jadi orang yang rumahnya berlantai marmer lebih fakir dibanding orang yang hanya memiliki gubuk berlantai tanah. Begitu juga pakaian yang dikenakan, sutera ataupun katun tidak jadi persoalan.

Kriteria miskin ditegaskan al-Nawawî dalam al-Raudah adalah: "Miskin adalah orang yang memiliki harta untuk memenuhi kebutuhannya dan tidak mencukupi. Seperti orang yang butuh 10 tapi ia hanya mempunyai 7 atau 8. Masuk dalam maknanya adalah orang yang mampu bekerja untuk memenuhi kebutuhan dan tidak mencukupi, sama juga harta yang dimiliki itu telah sampai satu nishab, kurang atau lebih dari nishab. Tidak dianggap dalam miskin harus meminta-minta. Demikian pendapat mayoritas Ashhab. Sementara sebagian ashhab menukil dari qaul qadim mengharuskan meminta-minta. Jika kamu telah mengerti fakir dan miskin maka kamu tahu bahwa fakir kondisinya lebih parah dari pada miskin. Ini adalah pendapat yang benar. Abu Ishak almawarzi justru membaliknya (miskin lebih parah kondisinya dari pada fakir)." (Al-Nawawî, tt: 205)

Sementara dalam kitab Majmu' dikatakan: “Adapun hakikat miskin, al-Shaf'i dan ashabnya berkata: ia (miskin) adalah orang yang mampu memenuhi kebutuhannya tetapi tidak mencukupinya. Ashab kami berkata: misalnya orang butuh sepuluh, ia hanya mampu atas 8 atau 7. Telah dijelaskan terdahulu dalam fasal fakir bahwa mampu bekerja sama seperti mampu atas harta, penjelasan pekerjaan dan harta yang mu'tabar sudah lewat. Fakir dan miskin keduanya diberi untuk kesempurnaan kifayahnya, cara pemberian kifayahnya dan segala cabang-cabang yang terdahulu juga sudah dibahas. Tidak ada perbedaan antara fakir dan miskin. Ashhab kami mengatakan sama saja harta yang dimiliki orang miskin itu satu nisab, kurang, maupun lebih dari nishab, 
jika tidak mencukupi kebutuhannya maka ia diberi untuk sempurnanya kebutuhan." (Al-Nawawi, tt: 197)

Dengan demikian, fakir adalah mereka yang mempunyai harta separuh atau kurang dari hajatnya. Sementara mereka yang mempunyai harta separuh lebih tapi tidak sampai dapat memenuhi kebutuhannya dan tidak sampai disebut kaya maka dinamakan miskin.

Penyebutan kata fuqarâ' baru kemudian masâkîn mengindikasikan bahwa fakir lebih sengsara daripada miskin, sebab dalam tradisi orang Arab selalu mendahulukan yang lebih penting. Dengan demikian, fakir lebih butuh.

Al-Kasâni memberi komentar dalam hal kadar kebutuhan yang harus dicukupi. Ia menyitir pendapat al-Karakhi yang menyatakan bahwa tidak ada halangan memberikan zakat bagi orang yang memiliki rumah dan perabotnya, pembantu, kuda, pedang, pakaian, dan buku-buku ilmiah (bagi ahlinya). Jika ia punya kelebihan dari harta tadi seharga 200 (dua ratus) dirham, maka haram baginya mengambil zakat sebagaimana hadits yang diriwayatkan Hasan Basri. Ia mengatakan bahwa mereka memberi zakat pada orang yang mempunyai kekayaan, seharga 10.000 dirham terdiri dari kuda, senjata, pembantu dan rumah. (Al-Kasani, tt: I/65)

Jadi kebutuhan-kebutuhan yang harus dipenuhi tidak sebatas terpenuhi makan minum, pakaian, dan rumah, akan tetapi meliputi juga pembantu, alat-alat pekerjaan, alat transportasi, dan buku-buku ilmiah (pendidikan).

Untuk mengetahui lebih jelas tentang kriteria dan parameter fakir miskin, penulis menggunakan logika terbalik, yakni dengan mengetahui batasan kaya. Orang yang sudah masuk dalam kategori kaya maka haram baginya atas harta zakat. Menurut Al-Kasani yang dikutip Yusuf Qardhawi, kaya itu terbagi menjadi 3 macam: 


\section{Kuntarno Noor Aflah}

1. Kaya yang menyebabkan kewajiban zakat, yakni orang yang memiliki satu nisab dari hartanya yang lebih dari kebutuhan dasarnya

2. Kaya yang haram mengambil zakat dan menerima sedekah tetapi tidak wajib zakat, yakni orang yang sudah berkewajiban zakat fitrah dan berkurban, total kekayaan sisa kebutuhannya melebihi 200 dirham.

3. Kaya yang haram meminta-minta dan tidak haram mengambil zakat adalah orang yang mempunyai bekal untuk satu harinya (Yusuf Qardhawi (terj), 2001 : 71-73).

Setelah melihat secara gamblang pola pikir fikih tentang kemiskinan, maka penulis akan menggunakan hal itu sebagai pisau analisis untuk membedah kriteria kemiskinan yang ada di Indonesia. Sebagaimana penjelasan di atas, bahwa metode penghitungan garis kemiskinan yang digunakan BPS adalah menggunakan pendekatan konsumsi kebutuhan dasar (basic needs approach), sehingga yang disebut miskin adalah ketidakmampuan dalam memenuhi konsumsi kebutuhan dasar, baik kebutuhan dasar makanan maupun kebutuhan dasar bukan makanan seperti sandang, perumahan, pendidikan, kesehatan dan sebagainya.

\section{Optimalisasi penyaluran zakat}

Organisasi Pengelola Zakat baik BAZNAS maupun LAZ sangat membutuhkan data dan kriteria mustahik. Mustahik zakat yang jumlahnya ada 8 golongan, terdiri fakir, miskin, amil, muallaf, hamba sahaya, gharim, sabilillah dan ibnu sabil, perlu didefinisikan secara kontekstual dan jelas. Jika 8 golongan penerima zakat pada zaman Nabi semuanya masih ada, apakah di masa sekarang juga masih berlaku dan masih ada, ataukah perlu reinterpretasi terhadap 8 golongan tersebut, sehingga perlu kajian lebih mendalam dan rutin. Contoh misalnya hamba sahaya (budak) dan fi sabilillah, apakah kategorisasi ini masih ada atau tidak, ini perlu didalami. 
Begitu juga dengan kategori fakir dan miskin. Luasnya aspek dan cakupan tentang kriteria fakir dan miskin, menjadikan studi dan kajian masih terus diperlukan. Hal ini dimaksudkan agar jangan sampai salah dalam menginterpretasikan sebuah syariat yang berujung pada kesalahan dalam penerapannya.

Salah satu hasil studi penerapan kriteria kemiskinan yang sangat efektif dan fungsi zakat sebagai pengentasan kemiskinan dibuktikan oleh Institut Manajemen Zakat (IMZ). Dalam laporan Indonesia Zakat and Development Report 2012, IMZ melakukan penelitian tentang peran zakat bagi pengentasan kemiskinan. Dalam penelitian ini IMZ sudah barang tentu menyusun kriteria kemiskinan terlebih dahulu sebelum menerapkannya pada pengentasan kemiskinan.

Penelitian ini mengambil sample sebanyak 16 Organisasi Pengelola Zakat (OPZ) di berbagai wilayah di Indonesia. Penelitian dan kajian ini merupakan kajian empirik dampak zakat terhadap pengentasan kemiskinan. Aktifitas penyaluran yang dilakukan lembaga zakat diteliti secara lebih mendalam sejauhmana zakat dapat memberikan pengaruh terhadap pengentasan kemiskinan bagi penerima zakat di masyarakat. (Mustafa Edwin Nasution, dkk. 2010: 10)

Hasil analisis menunjukkan bahwa penyaluran dan pendayagunaan zakat oleh Organisasi Pengelola Zakat (OPZ) berimplikasi positif dalam mengurangi beban kemiskinan. Secara umum, persentase rumah tangga miskin (penerima zakat) mengalami penurunan sebesar 21,11 persen. Persentase penurunan tingkat kemiskinan di periode 2010/2011 ini lebih tinggi dibandingkan periode sebelumnya. Tidak hanya jumlah rumah tangga miskin yang berkurang, dimensi kemiskinan lainnya, seperti tingkat kedalaman kemiskinan dan tingkat keparahan kemiskinan juga berhasil diturunkan. Selain itu, pendayagunaan zakat oleh OPZ mampu mempercepat menanggulangi kemiskinan 1,9 tahun dari 7 tahun menjadi 5,1 tahun. (Mustafa Edwin Nasution, dkk. 2010: 10) 


\section{Kuntarno Noor Aflah}

Pencapaian OPZ dalam mengurangi beban kemiskinan tersebut menjadikan zakat sebagai instrument potensial membantu upaya pemerintah dalam menanggulangi kemiskinan. Program pendayagunaan zakat oleh OPZ kini semakin kreatif dan mengarah pada pemberdayaan dan pengembangan masyarakat sehingga sinergi antara zakat dengan program penanggulangan kemiskinan pemerintah menjadi mungkin dan menjanjikan untuk pencapaian hasil pengentasan kemiskinan yang lebih baik. Tentunya hal ini tidak terlepas dari penyusunan kriteria kemiskinan yang sangat baik sehingga dapat digunakan dalam pengentasan kemiskinan.

\section{Simpulan}

Kajian ini menyimpulkan bahwa kriteria fakir miskin (kemiskinan) memiliki pengertian, parameter, dan standard yang beragam. Islam melalui interpretasi para ulama fikih mendefinisikan kriteria kemiskinan dengan berbagai pengertian dan ukuran. Adanya perbedaan pendapat ini dikarenakan term kemiskinan dalam Al-Quran dan hadits, yaitu "fakir" dan "miskin" memiliki banyak arti. Begitu juga dari sudut pandang regulasi di Indonesia, banyak parameter kemiskinan.

Di dalam UU No. 13 tahun 2011, tidak menjelaskan kriteria fakir miskin. BPS (Badan Pusat Statistik), BKKBN (Badan Koordinasi Keluarga Berencana Nasional), Bapenas, sebagai unsur pemerintah juga berbeda pendapat. Perbedaan ini menujukkan pintu ijtihad sangat terbuka.

Kriteria, pengertian, standard dan parameter kemiskinan menurut ketentuan Islam memiliki perbedaan. Madzhab Syâfi'î tidak menentukan standar kuantitatif untuk kemiskinan. Kemiskinan ukurannya hanyalah kebutuhan. Selama mereka tidak mampu menutup 50\% kebutuhan pokoknya, maka disebut fakir. Apabila hanya mampu menutup 70\% dari kebutuhan pokoknya maka dikategorikan miskin. Menurut Madzhab Hanâfî, standard kualitatifnya berbalik dengan Madzhab Syâfi'î. 
Kondisi miskin lebih parah daripada fakir. Sedangkan standar kuantitatifnya adalah satu nisab zakat atau setara 85 gram emas saat ini. Sedangkan BPS dan BKKBN merumuskan konsep dan standard kemiskinan dengan konsep ekonomi. Kemiskinan dikonseptualisasikan sebagai ketidakmampuan dalam memenuhi konsumsi kebutuhan dasar yang rumusannya disesuaikan kondisi daerah masing-masing.

Penyusunan kriteria kemiskinan yang sangat baik dapat digunakan dalam kajian tentang dampak zakat terhadap pengentasan kemiskinan. Seperti kajian yang dilakukan oleh IMZ pada tahun 2010 .

\section{Daftar Pustaka}

Abu Hamid Muhammad al-Ghazali, Al-Mustasyfa, Vol I, Dar al Fikr, Beirut, tt.

Alauddin Abu Bakr bin Mas'ud al-Kasani, Badai al-Shanai', Juz. I, Dar al-Fikri, Beirut, tt.

Al-Nawawî, Majmî' Syarh al-Muhadzdzab, Juz VI, Dar al-Fikr, Beirut, $\mathrm{tt}$.

Badan Pusat Statistik, Analisis dan Penghitungan Tingkat Kemiskinan 2008, BPS 2008

Badan Pusat Statistik, Analisis Data Kemiskinan Berdasarkan Data Pendataan Program Perlindungan Sosial 2011, BPS 2012.

Badan Pusat Statistik, Data dan Informasi Kemiskinan Kota 2013, BPS, Jakarta, tt.

Badan Pusat Statistik, Penghitungan dan Analisis Kemiskinan Makro di Indonesia 2014, BPS, Jakarta, tt.

Didin Hafidhuddin, Agar Harta Berkah dan Bertambah, Gema Insani Press, Jakarta, 2005.

Edi Suharto, Analisis kebijakan Publik Panduan Praktis Mengkaji Masalah dan Kebijakan Sosial, Alfabeta, Bandung, 2005. 


\section{Kuntarno Noor Aflah}

Izz al-Din Ibn 'Abd al Salam, Qawaid al-Ahkam Fi Mashalih al Anam, Dar al-Ahram, Kairo, tt.

Kuntarno Noor Aflah \& M. Nasir Tajang, Zakat E Peran Negara, FOZ, Jakarta, 2010.

M. Quraish Shihab, Wawasan Alquran, Mizan, Jakarta, 1996.

Muhammad Abu Zahrah, Usul al Figh, Dar al Fikr al 'Arabi, Beirut, 1958.

Muhammad Ibn Ahmad al-Ansori al-Qurtubi, Al-Jami' Li Ahkam al-Qur'an, 14, Dar al-Fikr, Beirut, 1987.

Muhyiddîn Abû Zakariyya bin Syaraf al-Nawawî, Raudhat alThâlibin wa 'Umdat al-Muftîn, Juz.II, Dar al-Fikr, Beirut, tt.

Nana Mintarti, dkk., Indonesia Zakat Development Report, 2012, IMZ, Jakarta, 2013.

Noor Aflah, (ed), Strategi Pengelolaan Zakat Nasional, FOZ, Jakarta, 2013.

Noor Aflah, Arsitektur Zakat Indonesia, UI Press, Jakarta, 2012.

Sudibyo Alimoeso, Makalah, Indikator Kemiskinan Menurut BKKBN, 2014

Tim Penyusun, Ensiklopedi Hukum Islam, Ichtiar Baru Vanhouve, Jakarta, 2002.

Titik Kurnianingsih, Standarisasi Kemiskinan BPS, (Makalah, 2014)

Yusuf Al-Qardhawi, Hukum Zakat (terjemahan), Lentera Antar Nusa, Jakarta, 1987.

Yusuf Al-Qardhawi, Musykilatul Figr wa Kaifa 'Alijuha al Islam, Beirut, Maktabah al-Risalah, 1985.

Yusuf Al-Qardhawi, Teologi Kemiskinan; Doktrin Dasar dan Solusi atas Problem Kemiskinan (terj), Mitra Pustaka, Yogyakarta, 2002.

www.bps.go.id

www.kompas.com

www.republika.co.id 